\title{
Leaf Anatomy and histochemistry of Macropeplus dentatus (Perkins) I. Santos \& Peixoto and Macropeplus ligustrinus (Tul.) Perkins (Monimiaceae) ${ }^{1}$
}

\author{
Fernanda Flores Costa ${ }^{2}$, Helena Regina Pinto Lima ${ }^{2,4}$, Maura Da Cunha ${ }^{3}$ and Inês da Silva Santos ${ }^{2}$
}

Recebido em 10/07/2009. Aceito em 2/07/2010

\begin{abstract}
RESUMO - (Anatomia e histoquímica foliar de Macropeplus dentatus (Perkins) I. Santos \& Peixoto e Macropeplus ligustrinus (Tul.) Perkins (Monimiaceae)). A família Monimiaceae está representada na região Neotropical por seis gêneros. Macropeplus Perkins é um gênero, exclusivamente brasileiro, constituído por quatro espécies restritas às Florestas Alto-Montanas e que carecem de estudos anatômicos. O presente trabalho visa caracterizar a estrutura anatômica e a histoquímica da folha de Macropeplus ligustrinus (Tul.) Perkins e Macropeplus dentatus (Perkins) I. Santos \& Peixoto, a fim de ampliar o conhecimento sobre esses táxons e auxiliar na taxonomia do gênero. Os indivíduos amostrados estão localizados no Parque Nacional da Serra dos Órgãos (RJ) e do Parque Natural do Caraça (MG). Dentre as características observadas comuns às espécies destacam-se: estrutura dorsiventral, folha hipoestomática, estômatos paracíticos, estrato subepidérmico, sistema vascular colateral em forma de arco no pecíolo, padrão de venação do tipo semicraspedobroquidódromo e presença de cristais prismáticos. Alguns metabólitos especiais foram identificados como substâncias fenólicas, lipídios e mucilagem, sendo o último detectado pela primeira vez na família. O contorno do pecíolo, a ocorrência e distribuição das células secretoras e das braquiesclereídes, em associação com os dados morfológicos, são úteis na distinção dessas espécies.
\end{abstract}

Palavras-chave: anatomia foliar, histoquímica, Macropeplus, Mata Atlântica, Monimiaceae

ABSTRACT - (Leaf anatomy and histochemistry of Macropeplus dentatus (Perkins) I. Santos \& Peixoto and Macropeplus ligustrinus (Tul.) Perkins (Monimiaceae)). The Monimiaceae is represented in the Neotropical region by six genera. Macropeplus Perkins is a Brazilian genus comprising four species restricted to high-montane Atlantic Forest areas, which have not been properly examined from the anatomical point of view. This study characterizes the anatomical structure and histochemical aspects of the leaves of Macropeplus dentatus and M. ligustrinus, and adds to our taxonomic knowledge of the genus. The individuals studied were collected in the Serra dos Órgãos National Park and in the Caraça Natural Park in southeastern Brazil. Among the characteristics common to the two species, hypostomatic leaves, dorsiventral structure, paracytic stomata, a subepidermal layer, collateral vascular system in the form of an arc in the petiole, semicraspedobrochidodromous venation, and the presence of prismatic crystals were registered. Intracellular metabolites, such as phenolic compounds, lipids and mucilage, were identified. The petiole shape, occurrence and distribution of secretory cells and brachysclereids, in association with other morphological features, were relevant to species identification.

Key words: Atlantic Rain Forest, histochemistry, leaf anatomy, Macropeplus, Monimiaceae

\section{Introduction}

The Monimiaceae (sensu stricto) comprises from 25 to 30 genera and approximately 200 species. Five genera have been previously described for the Neotropical region: Mollinedia Ruiz \& Pav., Macropeplus Perkins, Macrotorus Perkins, Hennecartia J. Poisson and Peumus Molina, while a sixth genus, Grazielanthus Peixoto \& Per.-Moura was only recently delimited (Peixoto \& Pereira-Moura 2008). From a biological point of view, the Monimiaceae is considered a key family for the understanding of the basal groups of angiosperms. Also, the presence of large quantities of essential oils in the majority of the Monimiaceae gives them pleasant odors as well as medicinal value. Among the economically important species, Peumus boldus Molina is widely used to treat liver problems (Peixoto et al. 2001; Santos \& Peixoto 2001).

The genera Mollinedia, Macropeplus, and Macrotorus occur in Brazil, and present similar characters at both the anatomical and morphological levels, and are therefore very difficult to separate. The close affinity of these three genera frequently leads to erroneous identification of the species, which are generally identified as Mollinedia (Santos \&
Peixoto 2001). There have been few studies focusing on the anatomy of the species of Macropeplus besides those of Metcalfe \& Chalk (1950) and Metcalfe (1987).

Macropeplus is an exclusively Brazilian genus that seems to grow only at altitudes above $1,000 \mathrm{~m}$ in forests and woodlands in "campos rupestres" (high-altitude rockygrassland vegetation), "cerrado" (savanna), high-montane Atlantic Forest, and transition areas between forests and high-altitude grasslands. It is considered a paleo-endemic genus, with distribution limited to areas within the Chapada Diamantina, Espinhaço, Mantiqueira, Mar, and Central Planalto mountains (Santos \& Peixoto 2001; Peixoto \& Pereira-Moura 2008).

Perkins (1898) described the genus Macropeplus from Mollinedia ligustrina Tul., making a new combination of Macropeplus ligustrinus (Tul.) Perkins and recognizing eight varieties for the species: M. ligustrinus var. dentata, M. ligustrinus var. friburgensis, M. ligustrinus var. pohlii, $M$. ligustrinus var. grandiflora, M. ligustrinus var. rhomboidea, M. ligustrinus var. typica, M. ligustrinus var. schwackeana, and M. ligustrinus var. xylophylla. Santos \& Peixoto (2001) synonymized the varieties created by Perkins (1898) based

\footnotetext{
Part of the Monograph of the first Author

2 Universidade Federal Rural do Rio de Janeiro, Departamento de Botânica, Seropédica, RJ, Brazil

Universidade Estadual do Norte Fluminense Darcy Ribeiro, Laboratório de Biologia Celular e Tecidual, Campos dos Goytacazes, RJ, Brazil

4 Corresponding author: helena@ufrrj.br
} 
on vegetative and reproductive morphological characters, and recognized four taxa: M. dentatus (Perkins) I. Santos \& Peixoto, M. friburgensis (Perkins) I. Santos \& Peixoto, $M$. ligustrinus (Tul.) Perkins, and M. schwackeanus (Perkins) I. Santos \& Peixoto. These authors distinguished the different species based on various vegetative characters such as type of leaf margin and consistency of the leaves as well as the colors they assume when dry. Additional reproductive characters were also used, such as length of pedicel, peduncle and floral lobes, and number of stamens.

Macropeplus dentatus is a rare, endemic species that occurs in sparse populations in the Serra do Mar Range in Rio de Janeiro state (RJ) and in the Serra da Mantiqueira Range in São Paulo state (SP), Brazil, while Macropeplus ligustrinus has a wider distribution, with populations found in the understory of riparian forests and valley forests in areas of "cerrado" and "campo rupestre" vegetation in the Cadeia do Espinhaço Range in Minas Gerais state (MG), in the Chapada Diamantina in Bahia state (BA), and in the Serra dos Pirineus Range in Goias state (GO) (Santos \& Peixoto 2001).

The selection of the two areas of this study was based on previous work by Santos \& Peixoto (2001) and PereiraMoura \& Peixoto (2004). Serra dos Órgãos National Park (RJ) covers approximately 11,800 hectares in the Serra do Mar Range, with altitudes that vary from $200 \mathrm{~m}$ to 2,263 m asl (IBAMA 2006), while Caraça Natural Park (MG) covers an area of 11,233 ha and is located in the Cadeia do Espinhaço Range (MG). The latter range occupies from 6,000 to $7,000 \mathrm{~km}^{2}$, with altitudinal variation between 900 and 2,000 $\mathrm{m}$, in the states of Minas Gerais and Bahia, where it is known as the Chapada Diamantina (Melo 2000).

This study aims to characterizes the leaf anatomy and histochemistry of $M$. dentatus and M. ligustrinus in order to increase our overall knowledge of these taxa.

\section{Material and methods}

Two individuals of Macropeplus dentatus were collected in the municipality of Teresópolis (RJ), in Serra dos Órgãos National Park at $1,940 \mathrm{~m}$ asl at the edge of the trail to Pedra do Sino. The local vegetation is classified as Dense Ombrophilous Forest and climate as type Cwb altitudinal tropical with a short dry season, according to the Köppen (1948) system (IBAMA 2006). Two individuals of M. ligustrinus were collected in the municipality of Catas Altas (MG) in Caraça Natural Park in the forest understory, at approximately $1,315 \mathrm{~m}$ asl along the trail to Gruta de Lurdes. At this site, the vegetation is transitional between Atlantic Forest and "cerrado" (Melo 2000).

The specimens of $M$. dentatus were deposited in the Botany Department Herbarium, Federal Rural University of Rio de Janeiro (RBR 16.793; RBR 16.974), and the specimens of M. ligustrinus were deposited in the Rio de Janeiro Botanical Garden Herbarium (RB 425.073; RB 425.074).

Fully expanded leaves were fixed in FAA in $70 \%$ ethanol (Johansen 1940). Distinct parts of the leaf blade and of the petiole were sectioned transversally and longitudinally and used to prepare semi-permanent slides. The sections were cleared with $50 \%$ sodium hypochlorite, neutralized in a $1 \%$ acetic acid solution, washed in distilled water, stained with a mixture of $2 \%$ Astra blue and $0.5 \%$ safranin in aqueous solution, and mounted with $50 \%$ glycerin (Bukatsch 1972).

The leaf blade was dissociated using a modified version of the technique developed by Occhioni (1948), stained with $1 \%$ safranin. Stomatal frequency was determined by examining a $1 \mathrm{~mm}^{2}$ area of leaf epidermis.
Twenty-five counts were made of each side of the leaf fragment and the averages were calculated. The stomata were classified according to Van Cotthem (1970).

In order to examine leaf venation, the leaves were cleared using a modification of the technique described by Foster (1949). The venation descriptions followed the classification system of Hickey (1979).

Histochemical tests were performed on fresh material sectioned using a Ranvier rotary microtome and then stained with: Sudan IV to indicate the presence of lipids and cutinized cell walls (Foster 1949); an alcohol solution of phloroglucinol chloridric to indicate the presence of lignin (Jensen 1962); Lugol solution for starch grains (Langeron 1949); 10\% potassium dichromate for phenolic compounds (Gabe 1968); Dragendorff for alkaloids (Effland 1977); $0.02 \%$ Ruthenium red for pectic substances (Jensen 1962); and 10\% chloridric acid to examine the nature of crystal inclusions (Strasburger 1986). An Olympus PM-C35B camera coupled to an Olympus CH30 microscope was used to record all microscopic images, and drawings were made using a camara-lucida apparatus coupled to a Wild M20 microscope.

For scanning electron microscope analysis, fully expanded leaf fragments were fixed in $2.5 \%$ glutaraldehyde, $4.0 \%$ paraformaldehyde and $0.05 \mathrm{M}$ sodium cacodylate buffer, $\mathrm{pH} 7.2$, post-fixed in $1 \%$ osmium tetroxide in the same buffer, for one hour, and dehydrated in acetone series. In addition, to verify the presence of epicuticular waxes, samples were boiled in chloroform for two minutes. The material was subsequently submitted to critical-point drying using a Bal-Tec CPD 030 Critical Point Dryer. The samples were affixed to supports using carbon adhesive tape and covered with a $20 \mathrm{~nm}$ layer of gold (Bal-Tec Sputter Coater SCD 050) and examined in a DSEM-ZEISS 962 scanning electron microscope.

\section{Results}

Macropeplus dentatus petiole presents outlines in transverse section slightly concave-convex in proximal and middle regions, and plano-convex in distal region (Fig. 1, 3, 5). In M. ligustrinus, the petiole outline is concave-convex along the entire shaft (Fig. 2, 4, 6).

The cortical region of $M$. dentatus has 10-12 layers of angular collenchyma while the equivalent region in $M$. ligustrinus has only six to nine layers (Fig. 7), and the cells on the abaxial side of both species are large. Brachysclereids were observed isolated and in groups dispersed throughout the collenchyma and near the vascular bundles in $M$. ligustrinus (Fig. 8-9), while in M. dentatus they were predominately found on the adaxial surface. Innumerous isodiametric idioblasts surrounded by radially arranged cells were dispersed within the collenchyma cells (Fig. 10). From three to five layers of parenchyma were observed in the innermost cortical portion along the entire petiole.

Perivascular fibers with cellulosic walls were observed in small groups near the vascular bundles (Fig. 11). The vascular system has a central discontinuous collateral bundle in the form of a flattened arc along the entire length of the petiole, with the arc extremities directed towards the adaxial side (Fig. 12). The xylem cells were organized in radial rows with four to six vessel elements per series.

Histochemical tests on the petiole indicated the presence of idioblasts with lipidic droplets and phenolic compounds in the collenchyma cells and near the vascular elements in both species (Fig. 13). Prismatic crystals of calcium oxalate were observed in the parenchyma and collenchyma cells, and starch grains were detected in the parenchyma cells, forming a starch sheath (data not shown). 

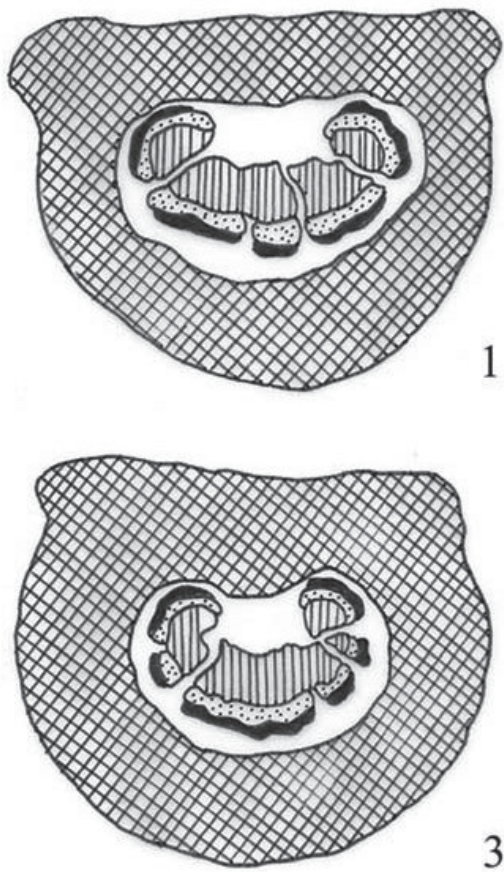

3

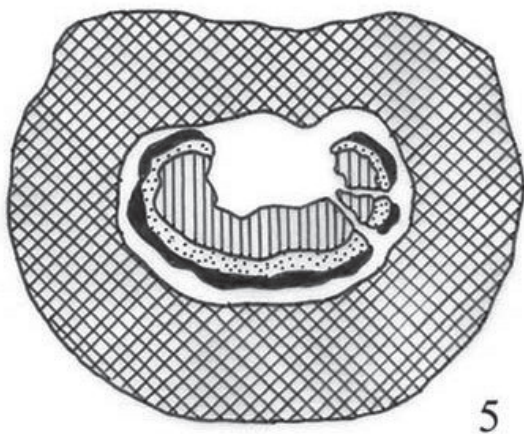

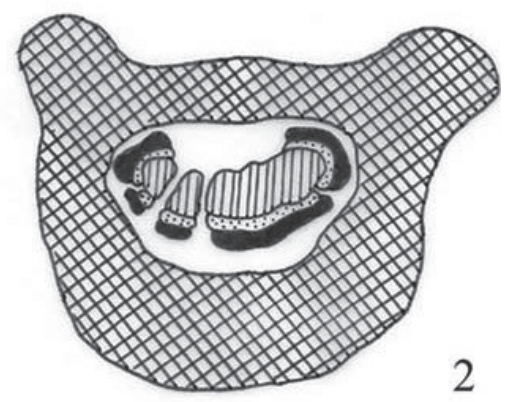

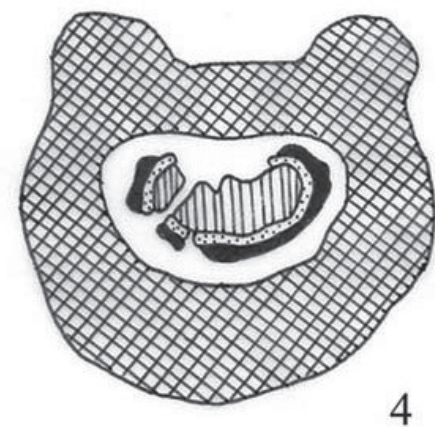

4

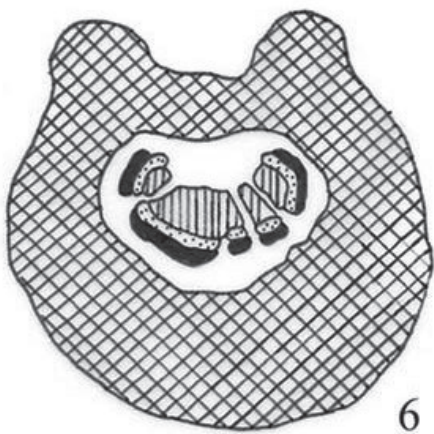

Figures 1-6. Diagram of the petioles in cross section, showing the arrangement of the vascular system. 1, 3, 5. Macropeplus dentatus (Perkins) I. Santos \& Peixoto. 2, 4, 6. Macropeplus ligustrinus (Tul.) Perkins. 1-2. Distal region. 3-4. Middle region. 5-6. Proximal region. Bar: 500 $\mu \mathrm{m}$ (1-6).

A smooth cuticle was observed on both surfaces of the leaf blade of M. ligustrinus (Fig. 14, 16), while in $M$. dentatus a slightly undulating cuticle was observed (Fig. 15, 17). A slightly rucose cuticular ornamentation was observed on the stomatal cells of M. ligustrinus, forming a mosaic design (Fig. 16). Both leaf surfaces in the species studied are covered with epicuticular wax film and large amount of microorganisms (Fig. 14-17).

The epidermal cells of $M$. dentatus and M. ligustrinus present anticlinal cell walls with straight to slightly sinuous outlines in frontal view on both surfaces (Fig. 18-19). Lipidic idioblasts were observed on the abaxial epidermis (Fig. 19), and seen in transverse section in the first layer of the spongy parenchyma (Fig. 20).

The leaves of $M$. dentatus and M. ligustrinus are hypostomatic, with paracytic stomata (Fig. 19). When viewed in transverse section, the stomatal cells in the central region have a wide lume with thin walls (Fig. 21). These stomata are situated at the same level as the other epidermal cells and there are sub-stomatal spaces that extend one or two layers into the spongy parenchyma (Fig. 21). Macropeplus dentatus demonstrated a stomatal density of $128 / \mathrm{mm}^{2}$ and M. ligustrinus had $86 / \mathrm{mm}^{2}$.

The subepidermal region of Macropeplus dentatus and M. ligustrinus is composed of one to two layers on the adaxial side either in the intercostal region or along the leaf blade. These cells do not contain chloroplasts and have thin cell walls (Fig. 22).

The mesophyll in both species is dorsiventral. Macropeplus dentatus had a two-layered palisade parenchyma and $M$. ligustrinus had a single palisade parenchyma. These species had 10-11-layered spongy parenchyma (Fig. 20, 

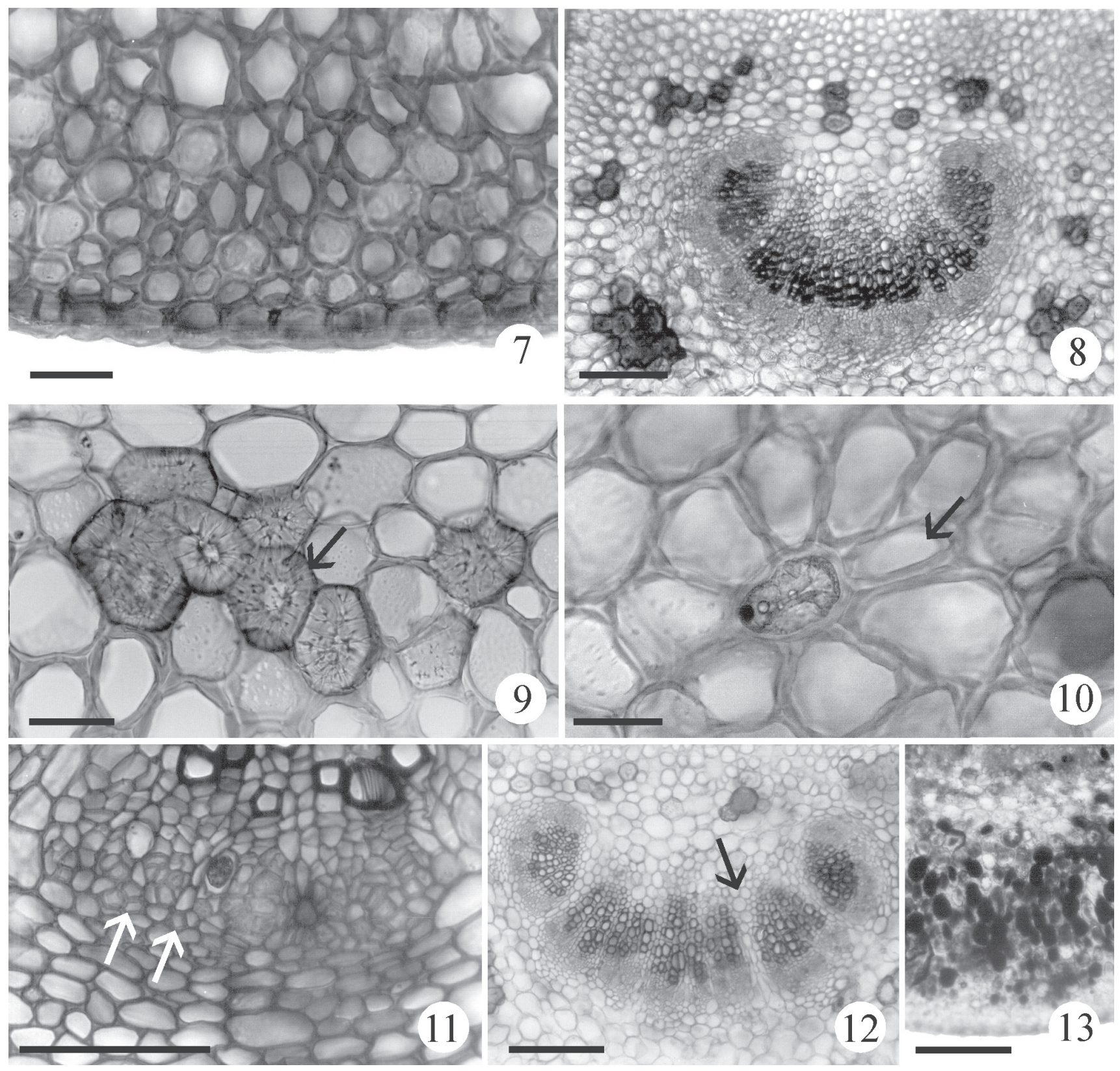

Figures 7-13. Anatomical aspects of the petiole middle region in cross section. 7. Detail of the Macropeplus dentatus abaxial surface. Note the angular collenchyma. 8. General aspect of Macropelus ligustrinus vascular system involved by brachysclereids. 9. Detail of brachysclereids in Macropeplus ligustrinus (arrow). 10. Detail of the Macropeplus dentatus idioblast. Note the radial disposition of the cells around the idioblast (arrow). 11. Detail of the vascular bundle. Note the cellulosic fibers (arrow). 12. Detail of the Macropeplus ligustrinus vascular system. Note the discontinuous vascular system (arrow). 13. Detail of idioblasts with phenolic compounds, of the Macropeplus dentatus. Bars: $25 \mu \mathrm{m}(7,9-11), 100 \mu \mathrm{m}(8,12-13)$.

22). The smaller veins had collateral vascular bundles with sclerenchymatous fibres and endodermis (Fig. 23).

The leaf margin tends towards the abaxial side, a trait more accentuated in M. ligustrinus. The cells of the subepidermal layer of the palisade and spongy parenchyma extend to near the leaf extremity, with a small decrease in cell dimensions. Angular collenchyma was observed in this region (Fig. 24).

In Macropeplus dentatus, the number of layers of angular collenchyma cells was similar both on adaxial and abaxial sides (Fig. 26). In the apical region only one or two layers were found on the adaxial side, and four to five on the abaxial side. In Macropeplus ligustrinus, there is a slight reduction in the number of layers of collenchyma in relation to $M$. dentatus (Fig. 26-29).

Lignified perivascular fibers are seen along the entire leaf blade, and these sometimes penetrated into the phloem, interrupting its continuity. These lignified cells were seen in greater proportions in M. ligustrinus, where 

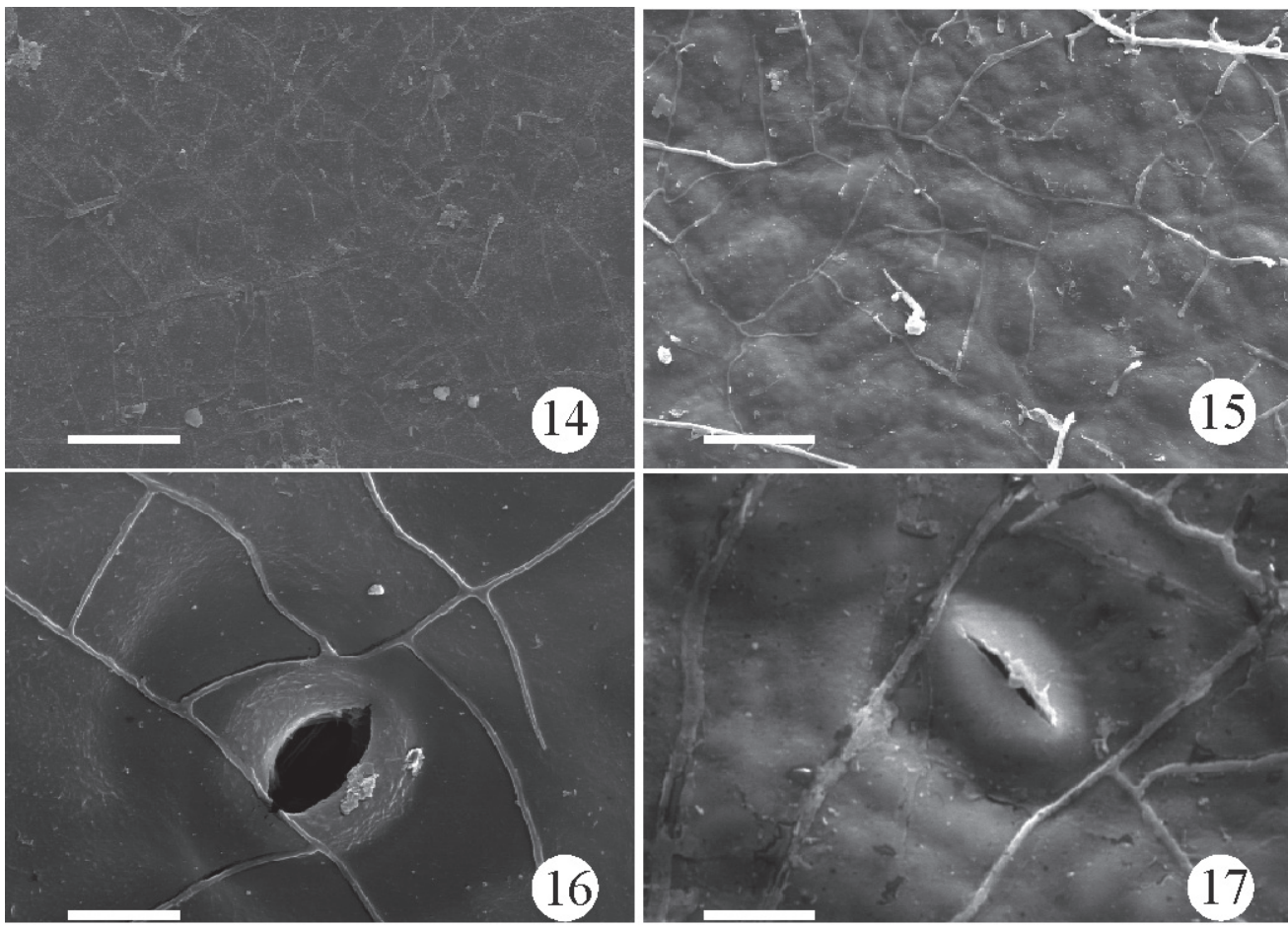

Figures 14-17. Leaf blade of Macropeplus ligustrinus and Macropeplus dentatus under scanning electron microscopy. 14. Macropeplus ligustrinus adaxial surface without ornamentations. Observe the presence of microorganisms. 15. Smooth adaxial surface of Macropeplus dentatus. Observe the presence of microorganisms and the rucose cuticular relief. 16. Macropeplus ligustrinus abaxial surface showing paracytic stomata. 17. Abaxial surface of M. dentatus showing paracytic stomata. Bars: $25 \mu \mathrm{m}(14-15), 10 \mu \mathrm{m}(16-17)$.
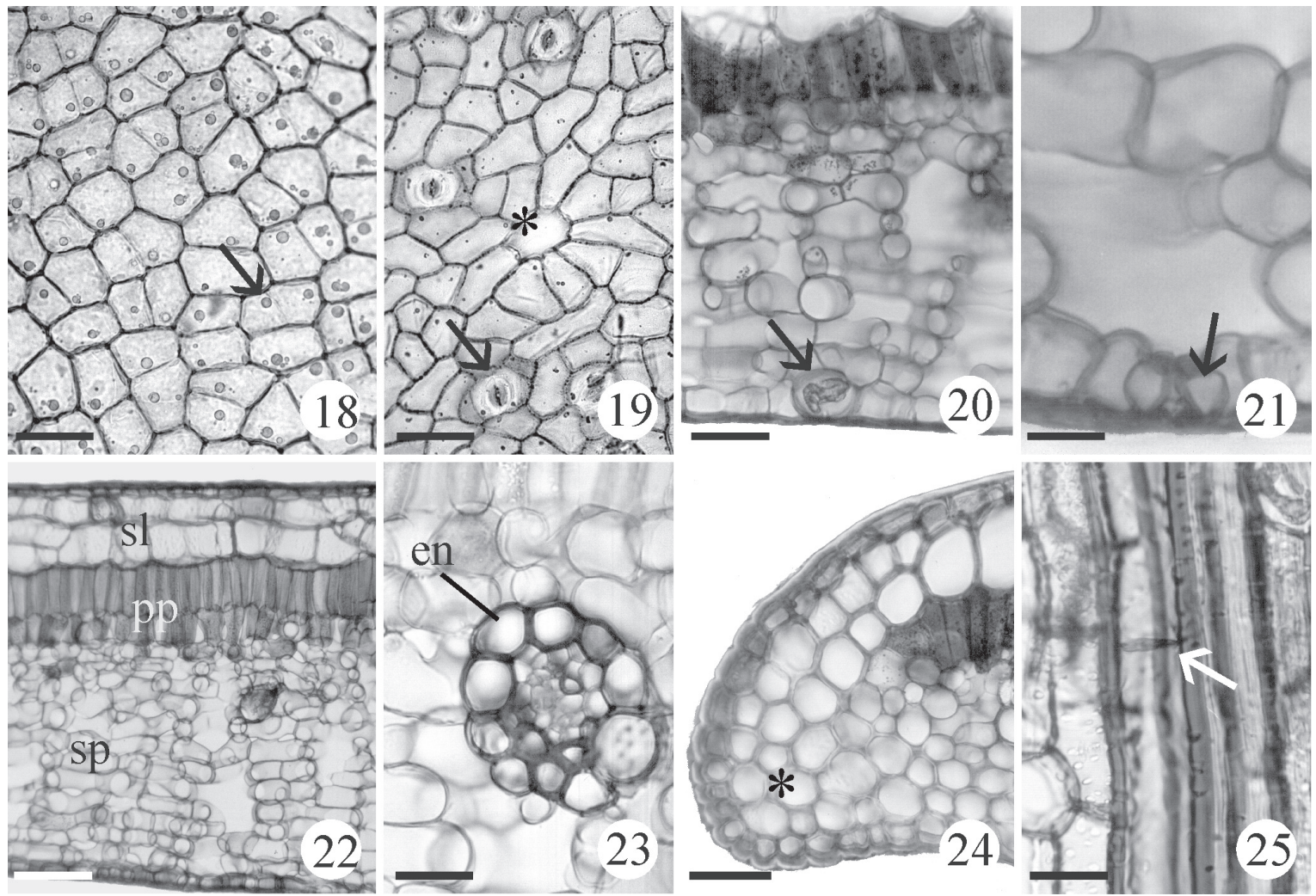

Figures 18 -25. Anatomical aspects of the leaf blade. Macropeplus ligustrinus (18-21 e 24) Macropeplus dentatus (22-23 e 25). Frontal view (18-19). 18. Adaxial epidermis (arrow $=$ lipid droplets). 19. Epidermis at abaxial surface (arrow = paracytic stomata; asterisk = lipid idioblast). Cross sections $(20-24) .20$. Epidermis at abaxial surface $($ arrow $=$ lipid idioblast). 21. Epidermis at abaxial surface (arrow = stomata with wide lumen). 22. General aspects of the mesophyll. 23. Vascular bundle. 24. Leaf margin (asterisk = angular collenchyma). 25. Longitudinal section of the midvein $($ arrow $=$ septate fiber). $(\mathrm{sl}=$ subepidermal layer; $\mathrm{pp}=$ palisade parenchyma; sp = spongy parenchyma; en = endodermis). Bars: $25 \mu \mathrm{m}(18,19-21,23-25), 100 \mu \mathrm{m}(22)$. 

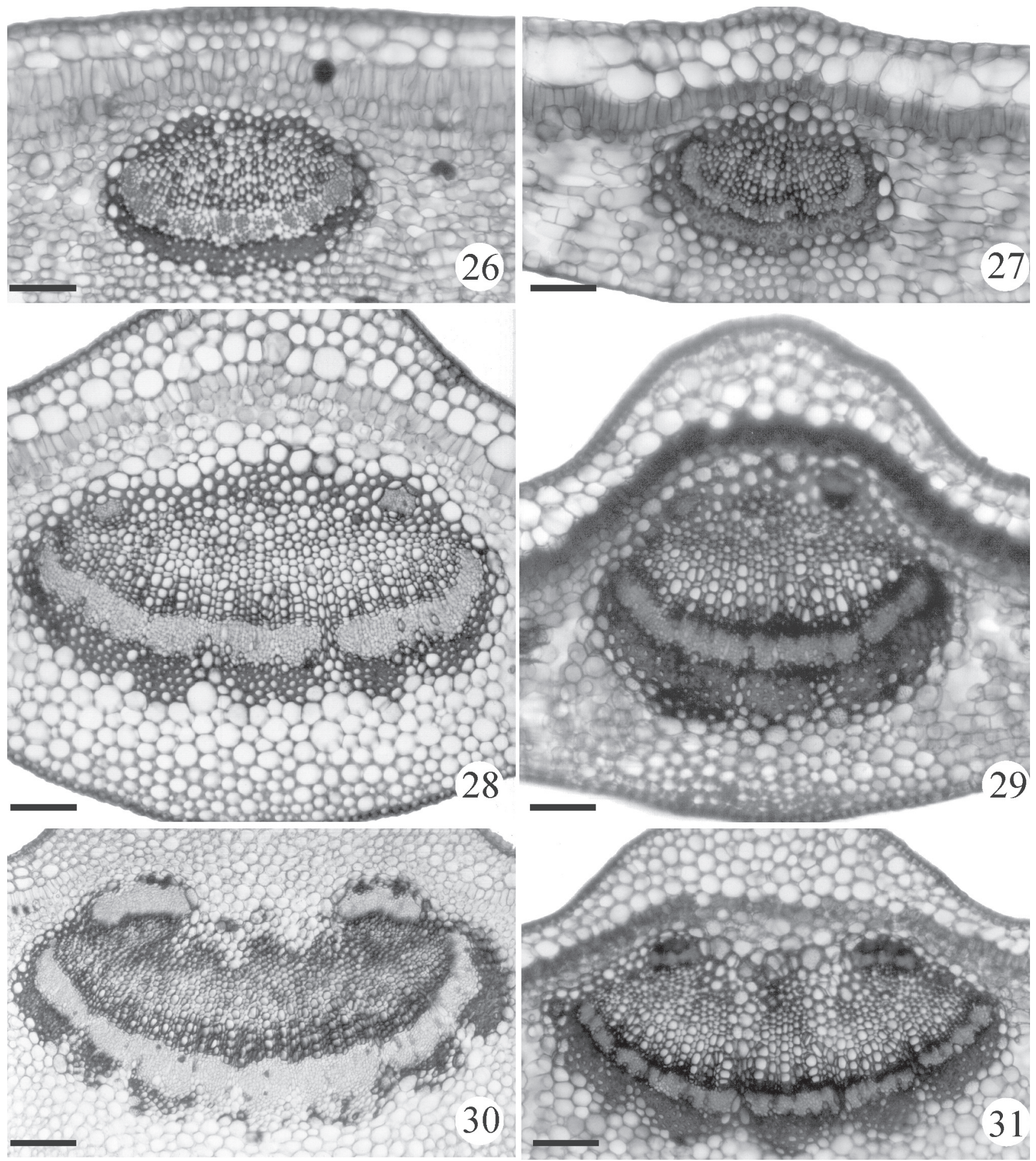

Figures 26-31. Cross section of the midvein of leaf blade. 26, 28, 30. Macropeplus dentatus. 27, 29, 31. Macropeplus ligustrinus. 26-27. Apical region. 28-29. Middle region. 30-31. Basal region. Bars: $100 \mu \mathrm{m}(26-31)$. 

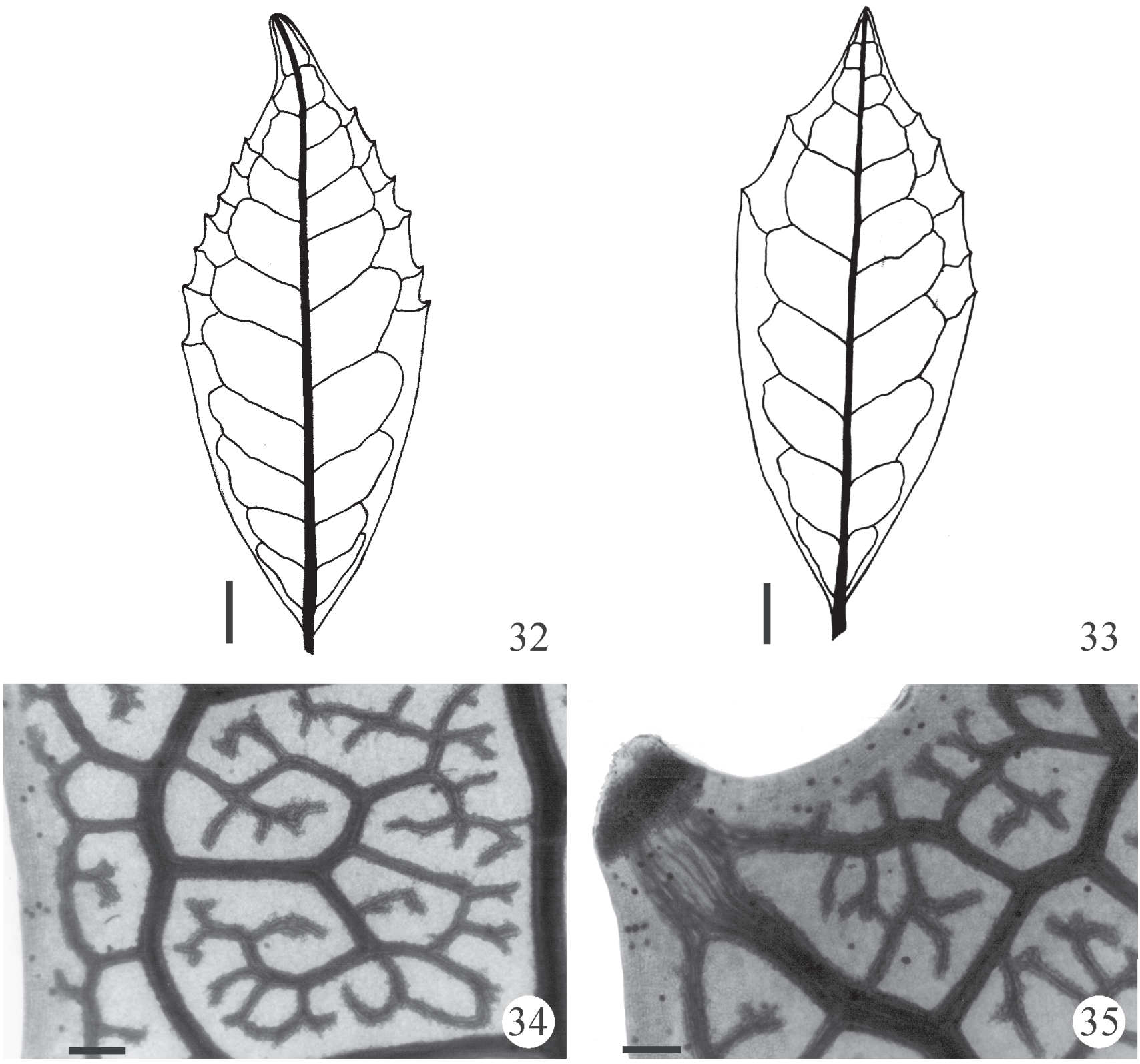

Figures 32-35. Leaf blade vascularization, in frontal view. 32-33. Semicraspedobrochidodromous venation pattern. 32. Macropeplus dentatus. 33. Macropeplus ligustrinus. 35. Vascularization of Macropeplus dentatus. Note loose venation, simple and branch vascular terminations, ultimate marginal venation is recurved forming loops and pentagonal areole. 35. Detail of vascular termination at the leaf margin of Macropeplus dentatus. Note apical mucronate termination of a tooth. Bars: $1 \mathrm{~cm}$ (32-33), $200 \mu \mathrm{m}(34-35)$.

they also had greater cell-wall thickening. Some of these fibers had cellulosic walls in the basal region of the leaves of $M$. dentatus. Septate fiber-tracheids were observed in longitudinal section in both species (Fig. 25).

A collateral vascular system is seen along the entire leaf blade of both $M$. dentatus and M. ligustrinus. The leaf apex in both species had a central arched bundle whose extremities were pointed towards the adaxial leaf side (Fig. 26-27). Besides the central arc, two to four smaller bundles are observed near the adaxial side in the middle and basal regions, being circular in transverse view in the middle and flattened in the basal region (Fig. 28-31). The vascular system in the middle region of $M$. ligustrinus leaf blade was smaller than that of $M$. dentatus (Fig. 28-29).

The species studied have a venation pattern of semicraspedobrochidodromous type (Fig. 32-33). The primary vein was sharply defined, narrowed towards the apex. The secondary veins are opposite and alternate, as well as ascendant on the same leaf. The tertiary veins had a random reticulation pattern, forming a loose venation. The final marginal venation is recurved, forming loops 
that sometimes were incomplete. The areoles are of the imperfect type, randomly disposed, and predominantly pentagonal shapes. The vascular terminations are simple, and one to three times branched (Fig. 34). The leaf margin has mucronate teeth (Fig. 35).

Histochemical tests indicated the presence of lipid droplets, mucilage, and phenolic substances in mesophyll and vascular leaf blade tissues of $M$. dentatus and $M$. ligustrinus; the epidermis contains only lipid droplets (Fig. 18-20).

\section{Discussion}

The anatomical features that were considered as diagnostic for Monimiaceae by Metcalfe \& Chalk (1950) and Metcalfe (1987) are: secretory cells, with clear or brown contents, frequently apperaring as transparent dots in the leaf; hairs exclusively non-glandular, mostly unicellular, and sometimes two-armed or tufted; stomata confined to the lower surface are anomocytic or paracytic types; an adaxial hypodermis consisting of 1-3 layers of cells larger than those of the epidermis; mesophyll usually including a single or, more rarely, two or more layers of palisade cells; crystals in the form of small needles present throughout the mesophyll, and small cubical and rhombohedral in the veins; a central vascular system in the form of a discontinuous arc whose extremities are curved towards the adaxial leaf surface.

Some characters were not previously reported for the genus Macropeplus (Metcalfe 1987), such as secretory cells containing lipidic droplets and phenolic compounds, surrounded by radially arranged cells, found in both species, and the brachysclereids, either dispersed around the vascular system in M. ligustrinus, or observed on the adaxial surface in M. dentatus. The petiole profile was used as a diagnostic character for identifying the two species.

Micromorphological aspects of the leaf surface often directly reflect plant adaptations to their natural habitats (Juniper \& Jeffree 1983). Barthlott (1981) observed that these features can often be used to separate taxa to the level of genus or species. This author also reported that leaves can have smooth or ornamented cuticular surfaces. The species studied had smooth cuticles on both leaf surfaces. Lightly cuticular ornamentations were observed on the stomatal cells of M. ligustrinus, nevertheless this character was not considered sufficient to separate the species.

Macropeplus dentatus and M. ligustrinus leaf surfaces presented slightly curved anticlinal cell walls very similar to the majority of the species previously described for the family (Peixoto 1979; Barros et al. 1997). According to Wilkinson (1979), environmental conditions are suggested to explain the shapes of the anticlinal walls of the epidermal cells. The species studied grew exposed to full sunlight, which would have influenced the shape of their cell walls. Both species have hypostomatic leaves, and paracytic stomata, as described for the species of Mollinedia (Peixoto 1979, Metcalfe 1987, Barros et al. 1997). Trichomes were not observed in these species, as registered in Macropeplus, Macrotorus, Schrameckia, and Xymalos by Metcalfe \& Chalk (1950).

One to two subepidermal layers were observed on the adaxial side of Macropeplus dentatus and M. ligustrinus, in agreement with Metcalfe \& Chalk (1950) who described as being composed of one to three layers of large cells. Barros et al. (1997) observed a single subepidermal layer, with cells larger than those seen in the epidermis of Mollinedia gilgiana and M. marliae. An ontogenetic study of the leaves of Mollinedia oligantha Perkins indicated that the subepidermal layer is formed by periclinal divisions of protodermal cells, thus constituting a multiple epidermis (Callado et al. 2006). These results indicate the need for additional ontogenetic studies with other genera of the Monimiaceae to elucidate the origin of the subepidermal layer.

The species studied had dorsiventral mesophyll, in agreement with previous descriptions of the Monimiaceae (Metcalfe 1987; Barros et al. 1997). In this case, the number of palisade parenchyma layers was used to distinguish $M$. dentatus that has two layers, from M. ligustrinus, with only one.

The bundle sheath is an endodermal layer that may contain Casparian strips, starch, and phenolic compounds. The endoderm of Macropeplus dentatus and M. ligustrinus presented Casparian strips on all of the leaf veins. According to Esau (1976), bundle sheaths are wrapped around vascular terminations in a manner that avoids exposing the xylem and phloem directly to the intercellular air spaces along their course through the leaf.

Lignified perivascular and cellulosic fibers can be observed in the midvein and in secondary veins along the entire leaf blade in both the species studied. Longitudinal sections indicated the presence of septate fiber-tracheid, which had been previously reported in woody sections of the Monimiaceae species (Metcalfe \& Chalk 1950; Metcalfe 1987). Septate fibers are widely distributed among the dicotyledons, and they generally retain living protoplasm and appear to be associated with reserve material storage (Esau 1976; Fahn 1985).

Macropeplus dentatus and M. ligustrinus have a collateral type of vascular system, in agreement with observations made by Barros et al. (1997) for other Monimiaceae species. The vascular systems of the two species studied here form a single central arc in the petiole, while a central arc with two associated vascular bundles are observed adjacent to the adaxial side in the middle and basal regions of the leaf blade, in agreement with the observations of Metcalfe (1987).

According to Peixoto (1979), venation patterns can be very useful in identifying some species of Mollinedia, and these patterns identify the genus as being brochidodromous. This author also pointed out that when the leaf margin is dentate, the secondary veins 
branch from the median region of the blade to the apex and then continue to the leaf margin, thus characterizing semicraspedodromous venation. The basal region of Macropeplus dentatus and M. ligustrinus leaves has a brochidodromous venation pattern, while the regions from the middle to apex have a semicraspedodromous pattern, due to the presence of teeth along the leaf margin. As such, the venation pattern of these species is considered to be semicraspedobrochidodromous. The presence of teeth with mucronate apices along the leaf margins of the species studied was described by Hickey (1979) as being characteristic of the Monimiaceae.

Secretory cells are common features in the Lauraceae and Monimiaceae (Hobein 1889) and contain clear or dark contents are often seen in the mesophyll and the epidermal layers of the Monimiaceae (Metcalfe \& Chalk 1950, Metcalfe 1987). Innumerous idioblasts containing phenolic compounds were distributed within the parenchyma, collenchyma and in the vascular bundles of the leaves of Macropeplus dentatus and M. ligustrinus, as also observed in Mollinedia gilgiana and M. marliae (Barros et. al. 1997). Prismatic crystals of calcium oxalate occur in the collenchyma and parenchyma cells of the petiole and midvein of the leaf in both species. Calcium oxalate crystals are commonly seen and are considered to aid in protecting the plants against herbivory, in calcium regulation, and metal detoxification (Franceschi \& Nakata 2005).

Many authors have noted the presence of oil-secreting cells in the Monimiaceae, Hernandiaceae, and Lauraceae, all of which belong to the order Laurales (Metcalfe \& Chalk 1950; Metcalfe 1987; Gottlieb \& Salatino 1987). Lipid droplets were observed in secretory cells in the petioles and leaf blades of both species studied here, even though Metcalfe (1987) did not report these cells in the genus Macropeplus.

According to Metcalfe \& Chalk (1950), the absence of mucilaginous cells within the Monimiaceae is an important characteristic that distinguishes it from the Lauraceae. Mucilaginous cells were, however, observed in the two species examined here and, in addition to nullifying a diagnostic character previously considered to distinguish the two families, they may serve as a new character that can separate Macropeplus from other the genera of Monimiaceae.

Among the characters common to both species studied and relevant to the family as a whole, dorsiventral leaf structure, hypostomatic leaves, paracytic stomata, a subepidermal layer, collateral conducting system in the form of an arc in the petiole, semicraspedobrochidodromous venation, and the presence of prismatic crystals were relevant. The presence of mucilage is a new character for the Monimiaceae and may prove useful for distinguishing the genus Macropeplus. The distribution of the brachysclereids is an important characteristic for distinguishing the two species.
Additional anatomical, chemical, and molecular studies of the other two species will allow a better circumscription of the genus. Even though variations in leaf structure between the two species studied were relatively scarce, their association with other morphological features makes them relevant for species identification.

\section{Acknowledgements}

The authors would like to thank the Conselho Nacional de Desenvolvimento Científico e Tecnológico (CNPq), that granted a scholarship, the Fundação de Amparo à Pesquisa do Estado do Rio de Janeiro (FAPERJ) for financial support, and the Instituto Brasileiro do Meio Ambiente (IBAMA) for furnishing collecting permits. To the anonymous reviewers, for their valuable comments.

\section{References}

Barros, C.F.; Callado, C.H.; Da Cunha, M.; Costa, C.G.; H., Pugialli, H.R.P.; Marquete, O. \& Machado; R.D. 1997. Anatomia ecológica e micromorfologia foliar de espécies de floresta montana na reserva ecológica de Macaé de Cima. Pp. 275-296. In: Lima, H.C. \& GuedesBruni, R.R (eds.). Serra de Macaé de Cima: Diversidade Florística e Conservação em Mata Atlântica. Rio de Janeiro, Jardim Botânico do Rio de Janeiro.

Barthlott, W. 1981. Epidermal and seed surface characteristics of plants: Systematic applicability and some evolutionary aspects. Nordic Journal of Botany 1: 345-354.

Bukatsch, F. 1972. Bemerkungen zur Doppel färburng Astrablau-Safranin. Mikrokosmos 61: 255.

Callado, C.H.; Freitas, M.H.V.; Lima, H.R.P. \& Costa, C.G. 2006. Diferenciação da epiderme múltipla da lâmina foliar de Mollinedia oligantha Perkins. Floresta e Ambiente 12: 75-78.

Effland, M.J. 1977. Modified procedure to determine acid-insoluble lignin in wood and pulp. Teppi 10: 143-144.

Esau, K. 1976. Anatomia das plantas com sementes. São Paulo, Edgard Blucher.

Fahn, A. 1985. Anatomia vegetal. Madri, Ediciones Pirâmide.

Foster, A.S. 1949. Practical plant anatomy. New York, D. van Noatrand, Inc.

Franceschi, V.R. \& Nakata, P.A. 2005. Calcium oxalate in plants: formation and function. Annual Review of Plant Biology 56: 41-71

Gabe, M. 1968. Techniques histologiques. Paris, Masson \& Cie.

Gottlieb, P.J. \& Salatino, A. 1987. Função e evolução de óleos essenciais e de suas estruturas secretoras. Ciência e Cultura 39: 707-716.

Hickey, L.J. 1979. A revised classification of the architecture of dicotyledons leaves. Pp.25-39. In: C.R. Metcalfe \& L. Chalk (eds.). Anatomy of the Dicotyledons. Oxford, Claredons Press. v.I.

Hobein, M. 1889. Beitrag zur anatomischen charakteristik der Monimiaceen unter vergleichen der berüecksichtigung der Lauraceen. Botanische Jahrbücher 10: 51-74.

Ibama. 2006. Instituto Brasileiro de Meio Ambiente - Parque Nacional da Serra dos Órgãos. (http://www.ibama.gov.br/parnaso/). (Acesso em: 2/08/2006).

Jensen, D.H. 1962. Botanical histochemistry (principles and practice). São Francisco, W. H. Freeman and Company.

Johansen, D.A. 1940. Plant microtechnique. New York, McGraw-Hill Book Company.

Juniper, B.E. \& Jeffree, C.E. 1983. Plant surfaces. London, Edward Arnold. Köppen, W. 1948. Climatologia:con un estudio de los climas de la tierra. México, Fondo de Cultura Económica.

Langeron, M. 1949. Précis de microscopie. Paris, Massori et Cie.

Melo, E. 2000. Polygonaceae of the "Cadeia do Espinhaço" Brazil. Acta Botanica Brasilica 14: 273-300.

Metcalfe, C.R. 1987. Anatomy of the dicotyledons. Magnoliales, Illiciales, and Laurales. Oxford, Claredon Press.

Metcalfe, C.R. \& Chalk, L. 1950. Anatomy of the dicotyledons. Oxford, Claredon Press. 
Occhioni, P. 1948. Histologia e anatomia dos órgãos vegetais (raiz, caule, folhas e fruto). Contribuição ao Estudo da família Canellaceae. Arquivos do Jardim Botânico do Rio de Janeiro 8: 3-96.

Peixoto, A.L. 1979. Contribuição ao conhecimento da seção Exappendiculatae Perkins do gênero Mollinedia Ruiz et Pavon (Mollinedieae, Monimioideae, Monimiaceae). Rodriguésia 31: 135-222.

Peixoto, A.L, Reitz, R. \& Guimarães, E.F. 2001. Monimiáceas. Pp. 6-9. In: Reitz, R. (ed.). Flora Ilustrada Catarinense. Parte I. Herbário Barbosa Rodrigues, Itajaí.

Peixoto, A.L. \& Pereira-Moura, M.V.L. 2008. A new genus of Monimiaceae from the Atlantic Coastal Forest in South-eastern Brazil. Kew Bulletin 63: $137-141$
Pereira-Moura, M.V.L. \& Peixoto, A.L. 2004. Flora de Grão-Mogol, Minas Gerais: Monimiaceae. Boletim de Botânica da Universidade de São Paulo 22: 311-313.

Perkins, J. 1898. Beiträge zur kenntnis der Monimiaceae. I. Über die Gliederung der Gattungen der Mollinedieae. Botanische Jahrbücher fur Systematik, Pflazengeschite und Pflanzengeographie 25: 47-577.

Santos, I.S. \& Peixoto, A.L. 2001. Taxonomia do gênero Macropeplus Perkins (Monimiaceae, Monimioideae). Rodriguésia 52: 65-105.

Strasburger, E. 1986. Tratado de Botânica. Barcelona, Ed. Marin.

Van Cotthem, W.R.J. 1970. A classification of stomatal types. Botanical Journal of the Linnean Society 63: 246.

Wilkinson, H.P. 1979. The plant surface. Pp.97- 165. In: C.R. Metcalfe \& L. Chalk (eds.). Anatomy of the Dicotyledons. Oxford, Claredon Press. v.I.

Versão eletrônica do artigo em www.scielo.br/abb e http://www.botanica.org.br/acta/ojs 